\title{
REASONABLE ROYALTY PATENT INFRINGEMENT Damages: A Proposal for More Predictable, RELIABLE, AND REVIEWABLE STANDARDS OF AdMISSIBILITY AND PROOF FOR DETERMINING A REASONABLE ROYALTY
}

\author{
REID E. DODGE*
}

\section{INTRODUCTION}

Patents are vital to the United States economy. Abraham Lincoln alluded to the importance of patents when he said that patents "add[] the fuel of interest to the fire of genius, in the discovery and production of new and useful things." Indeed, many companies would cease to exist were it not for the limited-time monopoly granted by patents. ${ }^{2}$

In light of the importance of patents, it is equally important that the legal frameworks under which the United States patent system operates are robust; one such framework is the standard for assessing reasonable royalty damages. Reasonable royalty damages are one source of compensation for patent holders when they suffer harm due to patent infringement. ${ }^{3}$ In fact, they provide a last resort remedy for patent holders who can seek refuge nowhere else. ${ }^{4}$

In general, the reasonable royalty assessment contemplates what amount a willing licensee would have agreed to license the patent for when infringement began. ${ }^{5}$ In other words, the assessment seeks to determine "the difference between [the patent owner's] pecuniary condition after the infringement, and . . . if the

* J.D. Candidate, 2015, Indiana University Robert H. McKinney School of Law; B.S. 2012, Taylor University, Upland, Indiana. I owe a special thank you to my wife, Brooke, and family for their feedback and support throughout the writing of this Note. I would also like to thank Professor John R. Schaibley, III for his invaluable guidance about the substance of this material.

1. Lincoln's Patent, ABRAHAM LINCOLN ONLINE, http://www.abrahamlincolnonline.org/ lincoln/education/patent.htm (last visited Oct. 19, 2014), archived at http://perma.cc/M3JR-3ACM.

2. Intellectual Property, LILLY, http://www.lilly.com/about/key-issues/Pages/intellectualproperty.aspx (last visited Oct. 19, 2014), archived at http://perma.cc/AC8P-D9ZX ("The biopharmaceutical industry is dependent upon [patents] . . to develop and market the product."); 35 U.S.C. § 154(a) (2014) (the "limited-time monopoly" is "the right to exclude others from making, using, offering for sale, or selling the invention throughout the United States.").

3. See Georgia-Pacific Corp. v. U.S. Plywood-Champion Papers, Inc., 318 F. Supp. 1116, 1127 (S.D.N.Y. 1970) ("[R]easonable royalty is an alternative way of recovering general compensatory damages.”).

4. See Panduit Corp. v. Stahlin Bros. Fibre Works, Inc., 575 F.2d 1152, 1157 (6th Cir. 1978) ("When actual damages, e.g., lost profits, cannot be proved, the patent owner is entitled to a reasonable royalty.").

5. See Georgia-Pacific Corp., 318 F. Supp. at 1121 ("[The reasonable royalty assessment] requires consideration not only of the amount that a willing licensee would have paid for the patent license but also of the amount that a willing licensor would have accepted.").

http://dx.doi.org/10.18060/4806.0017 
infringement had not occurred." $\quad$ The assessment typically involves expert testimony utilizing a non-exclusive list of fifteen factors, commonly known as the "Georgia-Pacific factors." " Some of these factors include, for example, consideration of past licenses of the patent at issue, rates paid by the licensee for similar patents, and the nature and scope of the patent. ${ }^{8}$

Although a number of recent decisions have improved the reasonable royalty standard, it is not without fault. ${ }^{9}$ For example, some critics condemn the reasonable royalty framework because the assessments often result in astronomical awards. ${ }^{10}$ Others criticize the uncertainty that inherently results from juries applying the ubiquitous, predominantly qualitative, Georgia-Pacific factors in reaching a reasonable royalty verdict. ${ }^{11}$ Such uncertainty is exacerbated by the immense breadth with which courts admit reasonable royalty damages evidence. ${ }^{12}$ Needless to say, the current reasonable royalty standard has room for improvement.

The following hypothetical is illustrative of the relevant issues surrounding the reasonable royalty framework:

Party X sues Party Y for patent infringement. X's expert posits that reasonable royalty damages should amount to $\$ 50$ million after considering a "comparable" license totaling $\$ 48$ million and six other favorable Georgia-Pacific factors amounting to a $\$ 2$ million increase.

Y's expert submits an opinion approximating reasonable royalty damages at $\$ 1$ million by looking at a $\$ 1.2$ million "comparable" license and four other favorable Georgia-Pacific factors that decrease the amount by $\$ 200,000$.

On review, the judge determines that at least two factors from $Y$ 's expert's Georgia-Pacific factor analysis should not have been admitted under the Daubert standard $^{13}$ and excludes the $\$ 200,000$ downward adjustment. $\mathrm{Y}$ is given the opportunity to submit a new expert report in

6. Lucent Techs., Inc. v. Gateway, Inc., 580 F.3d 1301, 1324 (Fed. Cir. 2009) (citation omitted).

7. See Georgia-Pacific Corp., 318 F. Supp. at 1120 (identifying fifteen factors to consider when conducting a reasonable royalty assessment).

8. See id.

9. See Lucent, 580 F.3d at 1301; see also Uniloc USA, Inc. v. Microsoft Corp., 632 F.3d 1292 (Fed. Cir. 2011); ResQNet.com, Inc. v. Lansa, Inc., 594 F.3d 860 (Fed. Cir. 2010).

10. See, e.g., Michael J. Mazzeo et al., Patent Damages and the Need for Reform, PATENTLY-OBLOG, http://www.patentlyo.com/patent/2011/03/patent-damages.html (last visited Oct. 19, 2014), archived at http://perma.cc/3ZBN-UCJ7.

11. See, e.g., Bo Zeng, Lucent v. Gateway: Putting the "Reasonable" Back into Reasonable Royalties, 26 BERKELEY TECH. L.J. 329, 334 (2011) ("In the last decade, the uncertainty in the reasonable royalty standard has been exploited").

12. See Apple Inc. v. Motorola, Inc., 757 F.3d 1286, 1315 (Fed. Cir. 2014) ("The fact that one [reasonable royalty estimation method] may be said to more accurately value [an] aspect of a reasonable royalty calculation does not, necessarily, make the other approach[es] inadmissible.").

13. The standard for admitting expert testimony. See infra note 68 and accompanying text. 
light of the reviewing court's decision.

This hypothetical illustrates the unpredictability (admitting vastly different damage propositions) and inefficiency (dismissing all factors considered when only a few are insufficient) of the current reasonable royalty framework.

This Note proposes reform that will promote certainty-through predictability, reliability, and reviewability - while having the added benefit of simplicity, in that its implementation can be effected virtually immediately (i.e., without Congress' involvement). The proposal is two-fold. First, courts should require the use of comparable licenses as a starting point in every reasonable royalty analysis, and the court, in its gatekeeping role, should admit only the most comparable license for the jury's use as a damages award starting point. ${ }^{14}$ Second, courts should require experts to attach numerical associations to each Georgia-Pacific factor assessment such that any evidentiary review can efficiently and accurately evaluate the evidence. Then, as the damages assessment diverges from the comparable license starting point, courts should increase the scrutiny by which they admit these numerical factor associations.

To do this, Part I of this Note addresses remedies in patent law and why reasonable royalty damages are especially important. Part II presents a brief progression of the reasonable royalty framework. Part III presents the relevant issues plaguing the reasonable royalty framework. Finally, Part IV presents a proposal to remedy those problems.

\section{REMEDIES IN PATENT LAW}

Reasonable royalty damages serve a vital role in the United States patent system. They provide a "floor for damages" 15 and, consequently, incentivize innovation. ${ }^{16}$ This section outlines the vital role that reasonable royalty damages play under the general framework for patent infringement remedies and why attention should be focused on the integrity of the reasonable royalty standard. To begin, it is important to understand the underlying justifications for the United States patent system.

\section{A. The United States Patent System and Remedies}

Under the United States Constitution, "Congress shall have the power to . . . promote the Progress of Science and useful Arts, by securing for limited Times to Authors and Inventors the exclusive right to their respective Writings and

14. See generally Dan McManus, Incentives Must Change: Addressing the Unpredictability of Reasonable Royalty Damages, 5:1 AM. U. INTELL. PROP. BRIEF 1 (2014) (recently proposing something similar - giving juries the responsibility of choosing the more reasonable of the proposed royalty rates).

15. Whitserve, LLC v. Computer Packages, Inc., 694 F.3d 10, 26 (Fed. Cir. 2012) (citing Lucent Techs., Inc. v. Gateway, Inc., 580 F.3d 1301, 1324 (Fed. Cir. 2009)).

16. See U.S. CONST. art. I, $\S 8$, cl. 8 ("To promote the Progress of Science and useful Arts ....") (emphasis added). 
Discoveries." ${ }^{17}$ Pursuant to this constitutional power, Congress determined that patent law grants patent owners ("patentees") an exclusive property right: "the right to exclude others from making, using, offering for sale, or selling the invention." 18 The underlying goal of patent law is to incentivize innovation by temporarily granting an exclusive monopoly over all use of one's intellectual property in a patent. ${ }^{19}$ The rationale for granting such a monopoly is that, in its absence, an inventor might not acquire sufficient rewards for his investment in the innovation because others could freely appropriate the invention without the initial costs of research and development. ${ }^{20}$ Without adequate incentives, innovation is stunted by a lack of disclosure, as required in exchange for protection, and thus a lack of progress. ${ }^{21}$

With the understanding that exclusive property rights are granted to patentees, it is equally important to understand how this property right is enforced. By federal statute, "whoever without authority makes, uses, offers to sell, or sells any patented invention, within the United States or imports into the United States any patented invention during the term of the patent therefore, infringes the patent." 22 Injunctive relief and damages are the two basic remedies for patent infringement, ${ }^{23}$ but only reasonable royalty damages are assured for patent holders. ${ }^{24}$

\section{B. Injunctive Relief}

As the law currently stands, courts "may grant injunctions in accordance with the principles of equity to prevent the violation of any right secured by patent, on such terms as the court deems reasonable." 25 The United States Court of Appeals for the Federal Circuit ("the Federal Circuit"), which has exclusive jurisdiction over appeals arising under "any Act of Congress relating to patents," ${ }^{, 6}$ recently asserted that " $[\mathrm{o}] \mathrm{f}$ course the axiomatic remedy for trespass on property rights is

17. Id.

18. 35 U.S.C. $\S 154(a)(1)(2014)$.

19. Michael A. Greene, All Your Base Are Belong to Us: Towards an Appropriate Usage and Definition of the "Entire Market Value" Rule in Reasonable Royalties Calculations, 53 B.C. L. REV. 233, 235 (2012).

20. Id. at 236 .

21. Barry Ungar, The Paid-in-Full, Lump-sum Damage Award: A Perversion of GeorgiaPacific, Lucent v. Gateway and the Right to Exclude, 41 AIPLA Q.J. 205, 207 (2013).

22. 35 U.S.C. $\S 271$ (a) (2014).

23. See id. $\S 283$ ("The several courts having jurisdiction of cases under this title may grant injunctions in accordance with the principles of equity to prevent the violation of any right secured by patent, on such terms as the court deems reasonable."); $i d$. $§ 284$ ("Upon finding for the claimant the court shall award the claimant damages adequate to compensate for the infringement, but in no event less than a reasonable royalty").

24. DAVID J.F. GRoss ET AL., WinNing PATENT Litigation 277 (3d ed. 2012) (“[D]amages must not be less than a 'reasonable royalty.'").

25. 35 U.S.C. $\S 283$ (2014).

26. 28 U.S.C. $\S 1295(a)$ (2014). 
removal of the trespasser" (i.e., an injunction). ${ }^{27}$ However, in 2006, the longstanding tradition of presumptively granting this axiomatic remedy to a patentee whose rights had been infringed ${ }^{28}$ was upended in eBay, Inc. $v$. MercExchange, LLC. $^{29}$

In eBay, the United States Supreme Court dissolved the patent-specific presumption for granting an injunction in cases of patent infringement. ${ }^{30}$ In so doing, the court reasoned that remedies under patent law are not to be treated differently than remedies elsewhere in light of a lack of congressional intent to do so. ${ }^{31}$ The court reasoned that this is especially true because such "a major departure from the long tradition of equity practice should not be lightly implied." 32

Thus, in the post-eBay world of patent infringement remedies, injunctions are less certain, as patentees must go through a fairly cumbersome four-factor test to receive an injunction. A patentee must show:

(1) that the patentee has suffered an irreparable injury;

(2) that remedies available at law, such as monetary damages, are inadequate for that injury;

(3) that, considering the balance of hardships between the patentee and the accused infringer, a remedy in equity is warranted; and

(4) that the public interest would not be disserved by a permanent injunction. ${ }^{33}$

In light of this recent shift away from presumptively awarding injunctions to patentees who can prove infringement, ${ }^{34}$ patent damages have become all the more important.

\section{Damages}

In contrast to injunctive relief, the goal of damages for patent infringement is to provide adequate compensation to the patentee. ${ }^{35}$ In the case of patent

27. Presidio Components, Inc. v. Am. Technical Ceramics Corp., 702 F.3d 1351, 1362 (Fed. Cir. 2012).

28. See, e.g., Richardson v. Suzuki Motor Co., Ltd., 868 F.2d 1226, 1247 (Fed. Cir. 1989) (explaining that, absent a sound reason to the contrary, an injunction should issue against the infringer).

29. eBay Inc. v. MercExchange, LLC, 547 U.S. 388 (2006).

30. Id. at 394.

31. Id. at 391-92.

32. Id. at 391 (quoting Weinberger v. Romero-Barcelo, 456 U.S. 305, 320 (1982)).

33. Id.

34. See, e.g., Doris Johnson Hines, The Continuing (R)evolution of Injunctive Relief in the District Courts and the International Trade Commission, FINNEGAN (January/February 2013), http://www.finnegan.com/resources/articles/articlesdetail.aspx?news=3aad1 da2-08a9-4f14-a147611b1e39ff75, archived at http://perma.cc/MDV2-6ZS8 (noting a twenty percent drop in the rate of granting injunctive relief following eBay).

35. John Skenyon, PATENT Damages LaW AND PRACTICE $§ 1.1$ (2014). 
infringement, 35 U.S.C. $\S 284$ provides that "[u]pon finding for the claimant the court shall award the claimant damages adequate to compensate for the infringement, but in no event less than a reasonable royalty for the use made of the invention by the infringer, together with interest and costs as fixed by the court." In general, courts have interpreted $\S 284$ to provide "two alternative categories of infringement compensation"-(1) "the patentee's lost profits" and (2) "the reasonable royalty he would have received through arms-length bargaining. ${ }^{" 37}$ However, like the uncertainty in injunctive relief, ${ }^{38}$ an award of lost profits is uncertain, further highlighting the importance of reasonable royalty damages.

A patentee may recover lost profits as a measure of damages for the infringement by another under the notion that "but for" the infringer's acts, the patentee would have made more sales or earned a particular profit. ${ }^{39}$ However, proving lost profits is often difficult. ${ }^{40}$ To acquire damages in the form of lost profits, the Federal Circuit requires proof of four elements: "(1) demand for the patented product, (2) absence of acceptable noninfringing substitutes, (3) [the patentee's] manufacturing and marketing capability to exploit the demand, and (4) the amount of the profit [the patentee] would have made." ${ }^{41}$

Proving these requirements is cumbersome for a number of reasons. For example, many patentees do not commercialize their patents (e.g., research universities) $^{42}$ and as a result, they do not have any profits to lose (i.e., those entities that do not manufacture physical embodiments of their patents, which are commonly known as "non-practicing entities"). ${ }^{43}$ Moreover, even where patentees can prove the loss of profits, if the accused infringers could have

36. 35 U.S.C. $§ 284$ (2014).

37. Lucent Techs., Inc. v. Gateway, Inc., 580 F.3d 1301, 1324 (Fed. Cir. 2009).

38. See supra notes 25-34 and accompanying text.

39. See Crystal Semiconductor Corp. v. TriTech Microelectronics Int'1, Inc., 246 F.3d 1336, 1353-54 (Fed. Cir. 2001); Grain Processing Corp. v. Am. Maize-Prod. Co., 185 F.3d 1341, 1349 (Fed. Cir. 1999) ("To recover lost profits, the patent owner must show 'causation in fact,' establishing that 'but for' the infringement, he would have made additional profits.") (citation omitted).

40. Mark A. Lemley, The Boundaries of Patent Law: Distinguishing Lost Profits from Reasonable Royalties, 51 WM. \& MARY L. REV. 655, 657 (2009); see also Panduit Corp. v. Stahlin Bros. Fibre Works, Inc., 575 F.2d 1152, 1157 (6th Cir. 1978) (holding that lost profits are an inappropriate form of damages when costs and profits cannot be clearly demarcated even when all other lost profits elements are present).

41. Panduit Corp., 575 F.2d at 1156.

42. Michael Risch, Patent Troll Myths, 42 Seton Hall L. ReV. 457, 468 (2012).

43. Grain Processing Corp., 185 F.3d at 658-59; see also Thomas F. Cotter, Four Principles for Calculating Reasonable Royalties in Patent Infringement Litigation, 27 SANTA CLARA COMPUTER \& High TECH. L.J. 725, 728 (2011); John C. Jarosz et al., The Hypothetical Negotiation and Reasonable Royalty Damages: The Tail Wagging the Dog, 16 StAN. TECH. L. REV. 769, 788 (2013); Christopher B. Seaman, Reconsidering the Georgia-Pacific Standard for Reasonable Royalty Patent Damages, 2010 BYU L. REV. 1661, 1675 (2010); Zeng, supra note 11, at 335. 
feasibly resorted to noninfringing substitutes, then the second lost profits element is not met. ${ }^{44}$ In other words, courts have interpreted the second lost profits element to preclude lost profits where a noninfringing substitute is not on the market, but the accused infringer foreseeably could have developed or chosen a noninfringing alternative. ${ }^{45}$ In light of the difficulty of proving lost profits, it is not surprising that recent studies show that lost profits are becoming a less sought after form of damages. ${ }^{46}$ Needless to say, reasonable royalty damages are often all that stands between an infringer and his or her ability to freely appropriate the intellect and perseverance represented by the patents of bona fide inventors.

Reasonable royalty damages are generally calculated using standards that seek to determine at what value a willing patentee and a potential licensee would have agreed to license the patent, assuming the patent is valid and infringed ("the hypothetical negotiation"). ${ }^{47}$ In other words, the determination considers how much the patentee would have made in licensing royalties from the infringer if no infringement had occurred. ${ }^{48}$

The calculation of reasonable royalty damages generally involves the testimony of damages experts ${ }^{49}$ and a consideration of the ubiquitous, nonexclusive factors set forth in Georgia-Pacific Corp. v. U.S. Plywood Corp. ${ }^{50}$ However, the determination is fraught with uncertainty because of the lack of a predictable structural framework, as illustrated by the pertinent case law below. But before exploring the case law, it is helpful to review a progression of the reasonable royalty damages framework.

\section{LUCENT AND ITS PROGENY}

Recently, the reasonable royalty framework has changed substantially, and arguably for the better, but the legal framework still has room for improvement. Judge Richard A. Posner, widely renowned for his thoughts on law and economics, recently asserted, "the law relating to damages relief in patent cases seems to be in disarray." $"$ This section will outline a progression of the

44. Lemley, supra note 40, at 658.

45. See Grain Processing Corp., 185 F.3d at 1349-53.

46. See infra note 92-93 and accompanying text; see also Merrit J. Hasbrouck, Protecting the Gates of Reasonable Royalty, 11 J. MARShall InTEll. Prop. ReV. 192, 194-95 (2011) (observing the same phenomenon); Seaman, supra note 43, at 1676 (same); Zeng, supra note 11, at 335 (same).

47. Rembrandt Social Media, LP v. Facebook, Inc., 561 Fed. App’x, 909, 912 (Fed. Cir. 2014) (citation omitted).

48. Id.; see also SKENYON, supra note 35, at $§ 1: 14$ (describing the hypothetical negotiation as seeking to determine "the actual royalty rate on which the patent owner and the infringer would have mutually agreed had they negotiated a patent license at the outset of the infringement.").

49. 35 U.S.C. $§ 284$ (2014) ("The court may receive expert testimony as an aid to the determination of damages or of what royalty would be reasonable under the circumstances.").

50. Georgia-Pacific Corp. v. U.S. Plywood-Champion Papers, Inc., 318 F. Supp. 1116, 1116 (S.D.N.Y. 1970); see infra note 64 and accompanying text.

51. John Bone et al., An Interview with Judge Richard A. Posner on Patent Litigation, SRR 
reasonable royalty standard to the framework currently in place, which is unpredictable, unreviewable, and consequently in need of reform.

\section{A. The Reasonable Royalty Standard, in General}

To reiterate, to calculate a reasonable royalty, litigants often consider a hypothetical negotiation, ${ }^{52}$ which "assumes that the asserted patent claims are valid and infringed." ${ }^{, 3}$ In other words, the hypothetical negotiation is a "fantasy." 54 In reality, the patent was infringed, but in the determination of a reasonable royalty, courts try to determine what the hypothesized negotiators would have agreed to had negotiations for licensing actually taken place. ${ }^{55}$

Given the complex nature of the calculation, parties generally rely on expert testimony to support their reasonable royalty assertions. ${ }^{56}$ The expert generally determines both the "royalty base, which represents the revenue generated by the infringement," $" 57$ and the "royalty rate, which represents the percentage of revenue owed to the patentee." ${ }^{58}$ Needless to say, the reasonable royalty assessment is involved and complicated.

\section{B. The Georgia-Pacific Factors and the Daubert Standard}

As the relevant case law suggests, one of the difficulties in formulating a reasonable royalty framework is ensuring the evidence for a fictional scenario (i.e., the hypothetical negotiation) complies with the admissibility requirements for expert testimony under the Daubert standard. ${ }^{59}$ To do this, many experts formulate their reasonable royalty damage assessments by utilizing the GeorgiaPacific factors. ${ }^{60}$ Although these factors have stood the test of time, their misguided use in isolation can lead to an uncertainty that reasonable royalty assessments cannot afford.

JOURNAL, http://www.srr.com/article/interview-judge-richard-posner-patent-litigation (last visited Dec. 16, 2014), archived at http://perma.cc/K9LJ-PZ9L.

52. For example, Company A invents and patents a new light bulb filament. Company B hypothetically approaches Company A to purchase a license to manufacture and sell Company A's patented filament in its light bulb because of some perceived advantages. Company A hypothetically agrees and Company B begins light bulb production.

53. Lucent Techs., Inc. v. Gateway, Inc., 580 F.3d 1301, 1325 (Fed. Cir. 2009) ("The hypothetical negotiation ... assumes that the asserted patent claims are valid and infringed.").

54. Fromson v. W. Litho Plate \& Supply Co., 853 F.2d 1568, 1575 (Fed. Cir. 1988).

55. Id.

56. See, e.g., Whitserve, LLC v. Computer Packages, Inc., 694 F.3d 10, 32 (Fed. Cir. 2012).

57. Although important, a discussion of the royalty base is beyond the scope of this Note. See Greene, supra note 19 (discussing a proposal for modifying royalty base assessments).

58. Whitserve, LLC, 694 F.3d at 27 (citing Finjan, Inc. v. Secure Computing Corp., 626 F.3d 1197, 1208 (Fed. Cir. 2010)).

59. See infra note 68 and accompanying text.

60. Georgia-Pacific Corp. v. U.S. Plywood-Champion Papers, Inc., 318 F. Supp. 1116, 1120 (S.D.N.Y. 1970). 
To provide context, in Georgia-Pacific, the court found that one patent pertaining to "striated fir plywood," belonging to U.S. Plywood, was valid and infringed, warranting a damages calculation. ${ }^{61}$ In calculating damages, the court rejected the application of lost profits because U.S. Plywood's "proof of the probability of production and sales in any measurable quantity [was] unsupported by sufficient or adequate evidence." ${ }^{\prime 62}$ Thus, the proper measure of damages was to employ a reasonable royalty calculation. ${ }^{63}$ In issuing its opinion, the district court laid out the Georgia-Pacific factors as a guideline for the reasonable royalty calculation:

(1) The royalties received by the patentee for the licensing of the patent in suit, proving or tending to prove an established royalty;

(2) The rates paid by the licensee for the use of other patents comparable to the patent in suit;

(3) The nature and scope of the license, as exclusive or non-exclusive; or as restricted in terms of territory or with respect to whom the manufactured product may be sold;

(4) The licensor's established policy and marketing program to maintain his patent monopoly by not licensing others to use the invention or by granting licenses under special conditions designed to preserve that monopoly;

(5) The commercial relationship between the licensor and licensee, such as, whether they are competitors in the same territory in the same line of business, or whether they are inventor or promoter;

(6) The effect of selling the patented specialty in promoting sales of other products of the licensee, that existing value of the invention to the licensor as a generator of sales of his non-patented items, and the extent of such derivative or convoyed sales;

(7) The duration of the patent and the term of the license;

(8) The established profitability of the product made under the patent, its commercial success, and its current popularity;

(9) The utility and advantages of the patent property over the old modes or devices, if any, that had been used for working out similar results;

(10) The nature of the patented invention, the character of the commercial embodiment of it as owned and produced by the licensor, and the benefits to those who have used the invention;

(11) The extent to which the infringer has made use of the invention, and any evidence probative of the value of that use;

(12) The portion of the profit or of the selling price that may be customary in the particular business or in comparable businesses to allow for the use of the invention or analogous inventions;

(13) The portion of the realizable profit that should be credited to the invention as distinguished from non-patented elements, the

61. Id. at 1117 .

62. Georgia-Pacific Corp. v. U.S. Plywood Corp., 243 F. Supp. 500, 513 (S.D.N.Y. 1965).

63. Georgia-Pacific Corp., 318 F. Supp. at 1118. 
manufacturing process, business risks, or significant features or improvements added by the infringer;

(14) The opinion testimony of qualified experts;

(15) The amount that a licensor (such as the patentee) and a licensee (such as the infringer) would have agreed upon (at the time the infringement began) if both had been reasonably and voluntarily trying to reach an agreement; that is, the amount which a prudent licensee, who desired, as a business proposition, to obtain a license to manufacture and sell a particular article embodying the patented invention, would have been willing to pay as a royalty and yet be able to make a reasonable profit and which amount would have been acceptable by a prudent patentee who was willing to grant the license. ${ }^{64}$

It is not difficult to imagine how these fifteen factors can lead to disparate and largely qualitative opinions on the appropriate reasonable royalty award without some parameters under which they should be considered.

One such parameter on the Georgia-Pacific factors is the "gatekeeping" power given to judges under the Daubert standard. ${ }^{65}$ Under the Daubert standard, district court judges are asked to exclude unreliable expert testimony. ${ }^{66}$ The Patent Reform Act of 2011 even emphasized that in patent cases district court judges should act as gatekeepers by considering the sufficiency of damages testimony before introducing the opinions into evidence for the jury's consideration. ${ }^{67}$ In determining whether such expert testimony is reliable, the Daubert standard requires courts to consider a nonexclusive list of factors, as laid out in Daubert v. Merrell Dow Pharmaceuticals. ${ }^{68}$

Generally, the Daubert standard acts as a guard against reasonable royalty testimony that is based on "subjective belief or unsupported speculation." 69 Because the Daubert standard is the threshold over which all expert testimony must traverse, it is important that any reasonable royalty standard allows expert testimony to comply with the Daubert standard's requisite quality. ${ }^{70}$ It is equally

64. Id. at 1120 .

65. FED. R. EvID. 104(a); Apple Inc. v. Motorola, Inc., 757 F.3d 1286, 1314 (Fed. Cir. 2014) ("[A] district court judge, acting as a gatekeeper, may exclude evidence if it is based upon unreliable principles or methods ....”).

66. Apple Inc., 757 F.3d at 1314.

67. Patent Reform Act of 2011, 112th Cong. 23 \$(a) (2011) ("Prior to the introduction of any evidence concerning the determination of damages, upon motion of either party or sua sponte, the court shall consider whether one or more of a party's damages contentions lacks a legally sufficient evidentiary basis.").

68. Daubert v. Merrell Dow Pharms., 509 U.S. 579, 593-94 (1993) ((1) whether others can or have objectively tested the expert's technique or theory; (2) whether the technique or theory has been the subject of peer review and publication; (3) the known or potential error rate of the technique or theory when applied; (4) the existence and maintenance of standards and controls; and (5) whether the scientific community has generally accepted the technique or theory).

69. Id. at 590 .

70. A similar standard, of relevance to this Note, exists for evaluating the sufficiency of 
important to recognize the broad discretion ${ }^{71}$ this framework gives judges to act as gatekeepers against unsupported expert assertions. ${ }^{72}$ The following cases illustrate how courts have evolved in trying to harmonize the use of the Georgia Pacific factors and the Daubert standard.

\section{The Swing of the Reasonable Royalty Pendulum}

Until 2011, reasonable royalty damages were sometimes calculated by employing a rule-of-thumb starting point commonly referred to as "the $25 \%$ rule." 73 The rule assumed that twenty-five percent of the profit from the sale of the infringing product would go to the patentee and the other seventy-five percent would remain with the infringing defendant. ${ }^{74}$ In practice, the $25 \%$ rule amounted to a "surrogate license to provide a royalty rate when no actual comparable license was identified." 75 The thought was that twenty-five percent of an infringer's profits, subject to generally minor adjustments by the other GeorgiaPacific factors, sufficiently approximated a royalty to which the parties would have agreed. ${ }^{76}$ Thus, for approximately half of a century, patentees enjoyed a generous presumptive starting point in reasonable royalty awards. ${ }^{77}$

However, the "pendulum appears to have swung back in favor" of a more tailored approach to reasonable royalty calculations ${ }^{78}$ due in part to the Federal Circuit's recent decision to upend the $25 \%$ rule in Uniloc USA, Inc. v. Microsoft Corp. ${ }^{79}$ In Uniloc, the court appropriately deemed the $25 \%$ rule as an "arbitrary, general rule, unrelated to the facts" and contrary to what is required by the hypothetical negotiation and the Daubert standard. ${ }^{80}$ As one commentator aptly remarked, "Uniloc explained that there must be a factual basis to associate the royalty rates used in prior licenses to the particular hypothetical negotiation at

expert testimony on post-trial motions (e.g., motions for judgment as a matter of law and a new trial). See, e.g., Whitserve, LLC v. Computer Packages, Inc., 694 F.3d 10, 28-32 (Fed. Cir. 2012) (analyzing whether a new trial on damages was warranted because the expert's testimony was "impermissible speculation").

71. See Kumho Tire Co. v. Carmichael, 119 S. Ct. 1167, 1176 (1999) (“[W]e conclude that the trial judge must have considerable leeway in deciding in a particular case how to go about determining whether particular expert testimony is reliable.") (emphasis added).

72. See also Hasbrouck, supra note 46, at 215-16; Seaman, supra note 43, at 1705-06; Zeng, supra note 11 , at $357-65$.

73. See Uniloc USA, Inc. v. Microsoft Corp., 632 F.3d 1292 (Fed. Cir. 2011).

74. See id. at 1312-15.

75. Roy J. Epstein \& Paul Malherbe, Reasonable Royalty Patent Infringement Damages After Uniloc, 39 AIPLA Q.J. 3, 12 (2011).

76. Id. at 14-15.

77. Robert Goldsheider et al., Use of the 25 Per Cent Rule in Valuing IP, 37 LES NouvELLES 123, 123 (2002).

78. Cotter, supra note 43 , at $732-33$.

79. Uniloc USA, Inc. v. Microsoft Corp., 632 F.3d 1292 (Fed. Cir. 2011).

80. Id. at 1313 . 
issue in the case." 81

Other recent decisions from the Federal Circuit similarly illustrate that the pendulum has swung back to a more fact-specific analysis in coming to a reasonable royalty award. For example, in Lucent Technologies, Inc. v. Gateway, Inc., the Federal Circuit criticized the plaintiff's failure to submit evidence of royalty rates from other licenses that were adequately comparable to the patent at issue. ${ }^{82}$ The patent at issue related to a minor software feature that allowed users to enter information into fields on a computer screen without the use of a keyboard. $^{83}$ In remanding for a new trial on damages, the court found it impossible to determine the comparability of the licenses partially because the plaintiff justified the admission of such evidence by merely explaining that they covered "PC-related patents." ${ }^{4}$ Thus, like the conclusion in Uniloc, Lucent stands for the proposition that under the current reasonable royalty standard more effort must be directed toward adequately evaluating the comparability of other licensing agreements. ${ }^{85}$

In the wake of recent precedent, ${ }^{86}$ it is apparent that the reasonable royalty framework has properly scaled back in favor of more fact-intensive reasonable royalty assessments in compliance with the Daubert standard. However, the demise of the $25 \%$ rule has likely had the debilitating effect of reducing certainty in reasonable royalty determinations ${ }^{87}$ - the overarching problem this proposal seeks to resolve.

\section{ISSUES SURROUNDING THE REASONABLE ROYALTY FRAMEWORK}

Patent litigation is on the rise and there is no indication that this rise will

81. Epstein \& Malherbe, supra note 75 , at 10.

82. Lucent Techs., Inc. v. Gateway, Inc., 580 F.3d 1301, 1339 (Fed. Cir. 2009); see also Georgia-Pacific Corp. v. U.S. Plywood Corp., 318 F. Supp. 1116, 1120 (S.D.N.Y. 1970) (listing

factors pertinent to the determination of the amount of a reasonable royalty for a patent license, and noting factor two as " $[\mathrm{t}]$ he rates paid by the licensee for the use of other patents comparable to the patent in suit.") (emphasis added).

83. Lucent Techs., Inc., 580 F.3d at 1309, 1328-32.

84. Id. at 1328 (explaining, "as if personal computer kinship imparts enough comparability to support the damages award.").

85. See also ResQNet.com, Inc. v. Lansa, Inc., 594 F.3d 860, 873 (Fed. Cir. 2010) (vacating damages award for considering licenses "without any factual findings that accounted for the technological and economic differences" between the licenses presented and the patent at issue); Wordtech Sys. v. Integrated Networks Solutions, 609 F.3d 1308, 1322 (Fed. Cir. 2010) (remanding for a new trial on damages for inadequately analyzing the comparability of the licenses considered). But see Kimberly A. Moore et AL., Patent Litigation and Strategy 981 (4th ed. 2013) (explaining that proponents of the $25 \%$ rule assert its accuracy is firmly based on empirical royalty data across all industries).

86. See Uniloc USA, Inc. v. Microsoft Corp., 632 F.3d 1292 (Fed. Cir. 2011); ResQNet.com, 594 F.3d at 860; Lucent Techs., Inc., 580 F.3d at 1301.

87. Infra note 121 and accompanying text. 
subside anytime soon (see Table 1). ${ }^{88}$ With the increase in patent litigation comes the need for robust frameworks adequate to consistently handle those caseloads. Indeed, "[t]he need for increased clarity and guidance has become a matter of crucial importance to parties involved in patent litigation." 89

Although progress has been made on the reasonable royalty framework, it is still short of robust. Instead, the framework is unpredictable and inefficient. These problems are compounded as a result of an increase in patentees seeking damages under the reasonable royalty framework combined with the general increase in the amount of patent litigation ${ }^{90}$ (see Table 1).

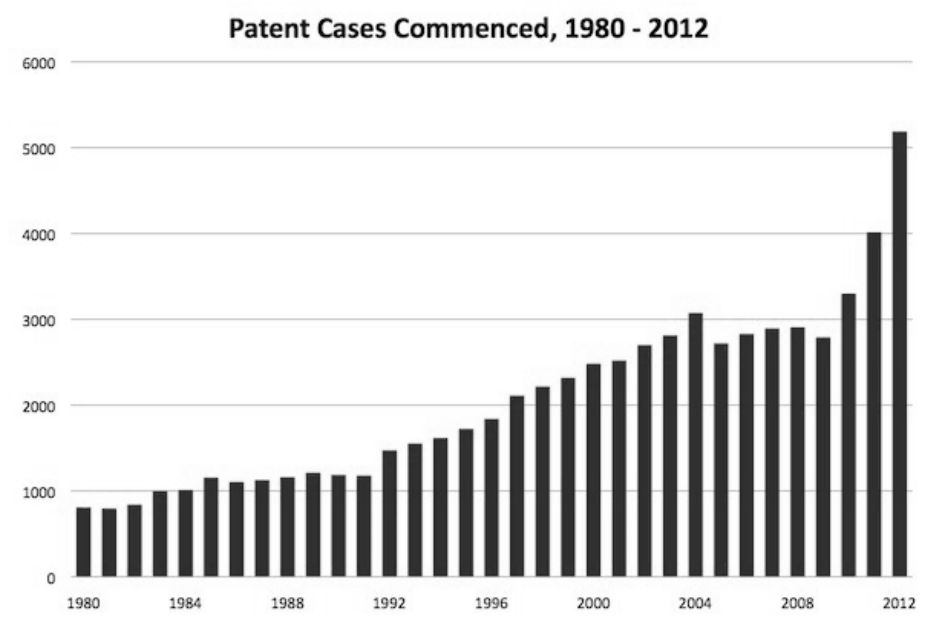

Table $1 .{ }^{91}$

For example, and as alluded to above, the basis for patent damages awards has shifted from 1995 to 2013. In 1995, sixty-nine percent of patent damages

88. See also Chris Barry et Al., 2014 Patent Litigation Study: As CASE Volume LEAPS, DAmAges Continue GENERAL DECLINE 5 (2014) (explaining that "the annual number of patent actions filed once again establishes a new record high"); Dennis Crouch, Patent Litigation Rates, PATENTLY-O BLOG, http://patentlyo.com/patent/2014/11/patent-litigation-rates.html (last visited Nov. 18, 2014), archived at http://perma.cc/A6QJ-CNUZ (noting a recent study showing that the increase in the number of patent lawsuits predictably tracks with the increasing rate of patents in force).

89. Erik S. Lee, Historical Perspectives on Reasonable Royalty Patent Damages and Current Congressional Efforts for Reform, 13 UCLA J.L. \& Tech. 1, 36 (2009) (citation omitted).

90. Zeng, supra note 11, at 335 (recognizing a similar relationship between reasonable royalty awards and an increase in jury trials).

91. Gene Quinn, The Rise of Patent Litigation in America: 1980-2012, IP WATCHDOG, http://www.ipwatchdog.com/2013/04/09/the-rise-of-patent-litigation-in-america-19802012/id=38910/ (last visited Oct. 19, 2014), archived at http://perma.cc/YS7Z-ZS5F. 
awards were in the form of a reasonable royalty. ${ }^{92}$ However, by 2013, eighty-one percent of patent damages awards were calculated using a reasonable royalty. ${ }^{93}$ Congress recognized this shift back in 2007 when it observed, "reasonable royalties have overtaken lost profits as the most frequent basis of damage awards in patent cases." 94 Thus, the importance of the integrity of the reasonable royalty framework cannot be understated. This section sets out the relevant operational issues plaguing the current reasonable royalty framework.

\section{A. Unpredictability}

First, the reasonable royalty framework is unpredictable. As illustrated in the introductory hypothetical, each side predictably presents evidence supporting a low reasonable royalty award or a high reasonable royalty award, whichever favors their client. ${ }^{95}$ However, there is little judicial constraint exercised on these disparate damages propositions. As one commentator aptly recognized, "because Georgia-Pacific permits the factfinder to consider virtually all potentially relevant evidence and give it whatever weight it deems appropriate, it is difficult to establish that an expert's reasonable royalty methodology is unreliable, so long as the expert professes some semblance of adherence to the Georgia-Pacific framework." ${ }^{\prime 96}$ Indeed, the Georgia-Pacific court, and others, have recognized the inherent imprecision with the fifteen-factor methodology it formulated. ${ }^{97}$

There must be a shift toward predictability in reasonable royalty determinations. As one commentator explained, "[p]atents require proper protection through . . . predictable results from the judiciary." of predictability, deleterious effects result (e.g., innovation becomes more of a liability in light of the threat of suits from non-practicing entities). ${ }^{99}$

1. In General.- The current framework is unpredictable, and unpredictability is contrary to the United States patent system rationale to incentivize innovation. ${ }^{100}$ Additionally, some commentators have explained the importance

92. BARRY ET AL., supra note 88 , at 10 .

93. Id.

94. Patent Reform Act of 2007, 110th Cong. 259 § 4 (2008) (citation omitted).

95. Seaman, supra note 43, at 1706.

96. Id.

97. Georgia-Pacific Corp. v. U.S. Plywood Corp., 318 F. Supp. 1116, 1120-21 (S.D.N.Y. 1970) (" $[\mathrm{T}]$ here is no formula by which these factors can be rated precisely in the order of their relative importance or by which their economic significance can be automatically transduced into their pecuniary equivalent."); see also Apple Inc. v. Motorola, Inc., 757 F.3d 1286, 1315 (Fed. Cir. 2014) ("This court has also recognized that estimating a 'reasonable royalty' is not an exact science.”).

98. Hasbrouck, supra note 46, at 193.

99. Infra note 123 and accompanying text.

100. U.S. ConsT. art. I, $\S 8$, cl. 8 ("To promote the Progress of Science and useful Arts ... ") (emphasis added); see also Christopher M. Holman, Unpredictability in Patent Law and Its Effect on Pharmaceutical Innovation, 76 Mo. L. REV. 645, 648-52 (2011) (explaining the deterrent effect of unpredictability on the patent system and innovation, in general). 
of predictability by recognizing that "damage awards in patent infringement suits serve a strong notice function" for both the potential value and licensing of the patent at issue. ${ }^{101}$

Currently, there are few definitive boundaries for the admission of reasonable royalty damages evidence. For example, in Apple Inc., the court reversed the district court's exclusion of two expert opinions that proposed reasonable royalty damages differing by a factor of $140 .^{102}$ The patents at issue related to smartphone technology. ${ }^{103}$ In its reasoning, the court explained that differences in the damages testimony go to the weight of the evidence, not its admissibility, because "the gatekeeping role of the judge is limited to excluding testimony based on unreliable principles and methods."104 However, it is difficult to imagine how two damages opinions differing by a factor of 140 could both be based on reliable principles and methods, as required by the Daubert standard.

Similarly, in i4i Limited Partnership v. Microsoft Corp., the patentee presented testimony that a reasonable royalty rate should be $\$ 200$ million, ${ }^{105}$ relying on a comparable technology license, while the accused infringer alleged that the award should be around $\$ 1$ million to $\$ 5$ million, ${ }^{106}$ relying on its own past licenses. The Federal Circuit reasoned that the patentee's expert's methodology was not flawed under the "highly deferential" standard of review, and the jury was justified in considering both propositions. ${ }^{107}$

As a less extreme example, in Parker-Hannifin Corp. v. Champion Laboratories, Inc., the plaintiff's expert opined that a reasonable royalty would amount to $\$ 2.50$ per unit, or a total of $\$ 254,405 .{ }^{108}$ The plaintiff's expert based his testimony in part on the incremental profit per unit they were earning. ${ }^{109}$ The

101. Axel Schmitt-Nilson, The Unpredictability of Patent Litigation Damage Awards: Causes and Comparative Notes, 3 AM. U. INTELL. Prop. BRIEF 53, 53 (2012) ("[D]amage awards in patent infringement suits serve a strong notice function. They demonstrate the value that can be extracted from a patent when used for it intended purpose.").

102. Apple Inc., 757 F.3d at 1326 (referring to Apple Inc. v. Motorola, Inc., No. 1:11-cv08540, 2012 WL 1959560, at*4 (N.D. Ill. May 22, 2012)).

103. Id. at 1295 .

104. Id. at 1315.

105. i4i Ltd. P'ship v. Microsoft Corp., 598 F.3d 831, 857 (Fed. Cir. 2010) (pertaining to a patent related to editing custom XML, a computer language used in Microsoft Word).

106. i4i Ltd. P'ship v. Microsoft Corp., No. 2009-1504, 2009 WL 2955399 (Fed. Cir. Aug. 25, 2009).

107. i4i Ltd. P'ship, 598 F.3d at 856-57; see also Lucent Tech., Inc. v. Gateway, Inc., 580 F.3d 1301, 1323 (Fed. Cir. 2009) (admitting the plaintiff's damages evidence of \$561.9 million and the defendant's damages evidence of \$6.5 million); McManus, supra note 14, at 3; Seaman, supra note 43, at 1707 (previously recognizing this same problem when expert opinions were admitted in Cornell University v. Hewlett-Packard Co. where the plaintiff's expert submitted a royalty award of $\$ 575$ million and the defendant's expert submitted a royalty award of \$2 million).

108. Parker-Hannifin Corp. v. Champion Labs., Inc., No. 1:06-CV-2616, 2008 WL 3166318, at *9 (N.D. Ohio Aug. 4, 2008) (pertaining to a patent related to engine filter technology).

109. Id. 
defendant's expert, however, asserted that a reasonable royalty would amount to $\$ 86,500$, after considering various licenses to similar technology. ${ }^{110}$ The court considered both testimonies relevant and concluded that a $\$ 203,524$ reasonable royalty was the appropriate remedy for the plaintiff. ${ }^{111}$

These cases illustrate that fact-finders are virtually unrestrained in the evidence they can consider in determining a reasonable royalty. Although reversed on appeal, ${ }^{112}$ Judge Posner, sitting by designation, wisely observed that, "[t]he size of the[se] dispari[ties] is a warning sign. Either one of the experts is way off base, or the estimation of a reasonable royalty is guesswork remote from the application of expert knowledge to a manageable issue within the scope of that knowledge." 113 This unpredictability is an enormous drain on resources; one example of the drain resulting from such unpredictability is the upper hand it gives to the infamous non-practicing entity ("NPE"). ${ }^{114}$

2. As It Relates to Non-practicing Entities.-NPEs, sometimes known as "patent trolls," are patent holders who earn the majority of their revenue through licensing or enforcing their patents. ${ }^{115}$ NPEs do not sell products or services, and thus, are virtually invulnerable to counter-claims because, by not commercializing their patents, they cannot infringe another patent. ${ }^{116}$ Unpredictability reinforces the litigation leverage already enjoyed by these NPEs. ${ }^{117}$ But before going into the significant leverage enjoyed by NPEs, it is important to understand why such leverage is possible.

One reason for the significant negotiating strength enjoyed by NPEs is that defending a patent infringement suit is an expensive endeavor. ${ }^{118}$ For example, in a 2013 report by the American Intellectual Property Law Association, the median cost of patent litigation through trial was approximately \$2.6 million. ${ }^{119}$ Furthermore, engaging in these lawsuits poses a substantial risk to accused infringers in that these reasonable royalty damage calculations are generally being decided by juries who may be easily confused by complex numerical valuation

110. Id. at *9-11.

111. Id. at $* 16$.

112. Apple Inc. v. Motorola, Inc., 757 F.3d 1286, 1326 (Fed. Cir. 2014).

113. Apple Inc. v. Motorola, Inc., No. 1:11-cv-08540, 2012 WL 1959560, at*4 (N.D. Ill. May 22, 2012).

114. What Is an NPE?, PATENTFREEDOM, http://www.patentfreedom.com/about-npes/ background (last visited Oct. 19, 2014), archived at http://perma.cc/2LFB-8NAD ("For companies facing it, NPE litigation is therefore particularly challenging. It can be highly distracting to management, which must pay money to outside counsel to defend itself, or to the 'other side' in order to secure a license, or both.").

115. Id.

116. Id.

117. Id.

118. See American Intellectual Property LaW Association, 2013 Report of the ECONOMIC SURVEY (2014).

119. $I d$. 
concepts. ${ }^{120}$ In light of the possible range of reasonable royalty awards, parties cannot readily assess the value of litigation, which often allows for what courts generally encourage - settlement. ${ }^{121}$ Without a predictable reasonable royalty framework under which patentees can readily assess the value of a case, the NPE gains a superior bargaining position.

For example, the astronomical costs of litigation favor settlements between the accused and the NPE regardless of the contention's validity. ${ }^{122}$ The following hypothetical is illustrative of the problem: "The patent troll offers a license for under $\$ 100,000$. The end user makes a business decision - millions of dollars to defend a suit that might be lost, or $\$ 100,000$ or less for certainty? The end user takes a license." 123 This hypothetical is a frequently recurring reality for accused infringers regardless of the validity of those accusations.

As a recent example, in Eon-Net LP v. Flagstar Bancorp, a NPE filed suit against over 100 defendants for allegedly infringing patents related to document processing systems. ${ }^{124}$ The bulk of those defendants "chose to settle early in the litigation." 125 The bold defendant who decided to fight paid $\$ 600,000$ in litigation costs to win the case, but only to avoid paying the offered settlement of $\$ 25,000$ to $\$ 75,000 .{ }^{126}$

The unfortunate reality illustrated by Eon-Net is not likely a rare occurrence. As recently highlighted in a patent troll report, the number of patent suits filed by "patent assertion entities" (those NPEs that actually assert the patents they do not practice) ${ }^{127}$ grew 526\% in just six years (466 in 2006 to 2,914 in 2012). ${ }^{128}$

120. Patent Reform Act of 2007, 110th Cong. $259 \S 4$ (2008) ("nor have [the factors] been presented to juries with sufficient guidance to ensure appropriate damages awards").

121. St. Louis Mining \& Milling Co. v. Mont. Mining Co., 171 U.S. 650, 656 (1898) ("settlements of matters in litigation or in dispute without recourse to litigation are generally favored.").

122. See Patent Reform Act of 2007, 110 th Cong. 259 § (2008) (“[L]itigation concerns can encourage unreasonable posturing during licensing negotiations, as well as premature settlements simply to avoid the high cost and uncertainty of patent litigation.").

123. Darren Cahr \& Ira Kalina, Of PACs and Trolls: How the Patent Wars May Be Coming to a Hospital Near You, 19 HeAlth LAWYer 15, 16 (2006).

124. Eon-Net LP v. Flagstar Bancorp, 653 F.3d 1314, 1316 (Fed. Cir. 2011).

125. Id. at 1326-27.

126. Id. Recently proposed legislation has the potential to remedy this problem by shifting the burden of fees to the losing party. See Saving High-Tech Innovators from Egregious Legal Disputes Act of 2013, H.R. 845, 113th Cong. (2013). Additionally, recent United States Supreme Court cases have lowered the burden necessary to obtain attorneys' fees in patent litigation. See Octane Fitness, LLC v. Icon Health \& Fitness, Inc., 134 S. Ct. 1749 (2014); Highmark Inc. v. Allcare Health Mgmt. Sys., Inc., 134 S. Ct. 1744 (2014); see also Andrew M. McCoy, Attorneys' Fee Awards in Patent Litigation-Emerging Trends, IND. L. REv. BLOG, http://indianalawreview. com/2014/11/13/attorneys-fee-awards-in-patent-litigation-emerging-trends-2/\#_edn2 (last visited Nov. 21, 2014), archived at http://perma.cc/MR8Q-XGKH (illustrating the likelihood of obtaining attorneys' fees post-Octane).

127. Colleen Chien, Everything You Need to Know About Trolls (The Patent Kind), 


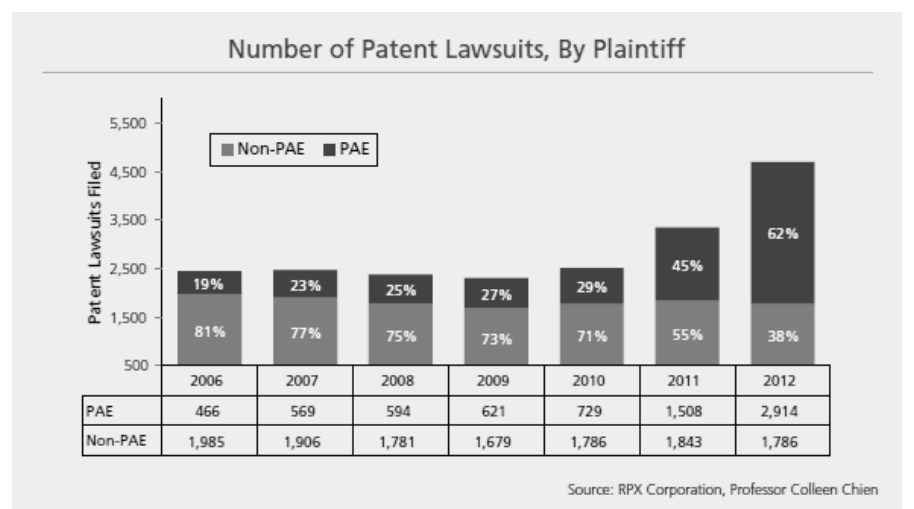

Table $2 .{ }^{129}$

The even more unfortunate reality, in light of these statistics, is that NPEs rarely prevail on the merits. Studies suggest that the win rates of NPEs are just eight percent compared to the forty percent patent litigation win rates of other entities. ${ }^{130}$ But because it is cheaper to settle, NPEs often "win" as a result of economic-driven concessions from accused infringers.

Clearly, the inability to readily evaluate the worth of a patent litigation case to make a decision as to whether to settle or carry the case through litigation is inefficient and contrary to the underlying incentives of the United States patent system. As one commentator remarked, "[c]lear and predictable patent damages rules that lead to fair damages awards encourage subsequent inventors to improve upon existing inventions." 131 However, under the current framework, innovation is often more of a liability than an asset.

\section{B. Nonreviewability}

In addition to the unpredictability of the current reasonable royalty framework, the framework makes it practically impossible to adequately review the damages evidence. This problem is particularly salient because of the recent rise in Federal Circuit reversal rates. ${ }^{132}$ Recently, "the Federal Circuit's reversal rate has approached $50 \%$ with the reasonable royalty damages being reversed in

WIRED.COM, http://www.wired.com/opinion/2013/06/everything-you-need-to-know-about-trollsthe-patent-kind (last visited Oct. 19, 2014), archived at http://perma.cc/AL3D-8M33.

128. A Report on the Litigation Industry's Intellectual Property Line of Business, TRIAL LAWYERS INC., http://www.triallawyersinc.com/updates/tli_update11.html (last visited Oct. 19, 2014) (citation omitted), archived at http://perma.cc/AW6M-WQNT.

129. $I d$.

130. Brian T. Yeh, An Overview of the "Patent Trolls" Debate (2013) available at www.fas.org/sgp/crs/misc/R42668.pdf(citation omitted), archived at http://perma.cc/WJ3Y-HMUX.

131. Hasbrouck, supra note 46, at 193.

132. SKENYON, supra note $35, \S 3: 2$. 
eight cases and affirmed in [ten]. Moreover, the reversals have often been because the reasonable royalty damages award was the result of faulty methodology and irrelevant or inadmissible evidence, and thus 'unsupported." 133 The unreviewability of evidence admitted under the Georgia-Pacific framework poses greater problems under a regime where reversals are becoming more common.

The reasonable royalty damages evidence is practically impossible to review, and thus reinforces the unpredictability of the current framework, in part because the evidence presented is not required to have a numerical assessment attached to the respective Georgia-Pacific factors utilized in coming to a damages opinion. The common application of the Georgia-Pacific factors leads to erratic results because "the judge throws the grab bag with all the factors to the jury and says, 'Do what you think is right." "134 Commentators have similarly observed that the Georgia-Pacific factors "can be so easily manipulated by the trier of fact to reach virtually any outcome" 135 because there is no meaningful guideline as to how much weight to give one factor over another. The problem for post-trial procedures is further exacerbated because juries are not required to support their verdict with the respective weight they give to each factor presented. ${ }^{136}$ When asked about the issues surrounding the reasonable royalty framework, Judge Posner recently observed, "the evidence that is presented by expert witnesses on damages [does not] seem on as high a level as the expert evidence presented on liability issues dealing with technology."137

Absent relative factor weights, courts have been reluctant to closely review a damages verdict or have thrown out the expert assessment altogether. For example, in Revolution Eyeware, Inc. v. Aspex Eyeware, Inc., the district court refused to throw out a jury verdict for damages even in light of the defendant's probable claims that the verdict was impossible to reach. ${ }^{138}$ In light of the "black box" that is the jury's deliberations, the court "[could] not say ... that the jury's verdict was inconsistent." 139 Nor could the court glean relative factor weights from the experts' testimony pertaining to the Georgia-Pacific factors. One example of an expert's use of the Georgia-Pacific factors in Revolution Eyeware was consideration of Factor 3: "the ... [comparable] license was non-exclusive, and therefore would presumably be of less value" than the exclusive license at issue. ${ }^{140}$ The court considered this qualitative assertion, albeit true, with the other

133. Id.

134. Seaman, supra note 43 , at 1704 (citation omitted).

135. Id. (citation omitted).

136. Id. at 1707 .

137. Bone et al., supra note 51.

138. Revolution Eyeware, Inc. v. Aspex Eyeware, Inc., No. CV 02-1087-VAP, 2008 WL 6873809 , at *10 (C.D. Cal. Apr. 24, 2008) (reasoning that because "[t]he jury was not required to report what prices, number of infringing units or percentage of value calculations it adopted," it was hard to say whether the jury's verdict was wholly unsupported).

139. Id. at *3 (citation omitted).

140. Id. at *7 (emphasis added). 
similarly evaluated factors, to be sufficiently "substantial evidence" to support a five percent reasonable royalty rate. ${ }^{141}$ Despite its conclusory substance, this is a representative sampling of the evidence courts have considered sufficient for admission to the jury and supportive of a reasonable royalty award. ${ }^{142}$

On the other end of the spectrum, in Dynetix Design Solutions, Inc. v. Synopsys, Inc., the court threw out the entirety of the plaintiff's expert report for its "arbitrar[iness]." 143 The plaintiff's expert considered Georgia-Pacific factors three, four, six, and eight through eleven without attaching quantitative values for each factor, which resulted in a $14.25 \%$ adjustment. ${ }^{144}$ In ruling on the Daubert motion, the court reasoned that the arbitrariness of the expert's assessment was predominantly connected to the expert's assertion that the starting point for the royalty rate was "half of the gross margin of the infringing products, i.e., dividing the profit margin of the infringing products evenly between the parties." 145 However, the court threw out the remainder of the expert's damages assessment relating to the Georgia-Pacific factors, likely assuming that analysis was likewise arbitrary. In other words, because the expert did not assign an adjustment number and corresponding rationale to each factor considered, the court could not adequately review the evidence, resulting in a waste of resources on expert testimony. Ultimately, the court permitted the expert to submit a new report on damages in compliance with its opinion. ${ }^{146}$

Other examples of experts throwing the Georgia-Pacific factors together and coming out with a "magic number" for a reasonable royalty award adjustment are illustrated in i4i Limited Partnership and Parker-Hannifin Corp. In i4i Limited Partnership, i4i's expert adjusted his baseline royalty rate by $\$ 2$ "[b]ased on all of [the considered] Georgia-Pacific factors."147 More specifically, i4i's expert considered five of the fifteen Georgia-Pacific factors as either supporting a higher or lower reasonable royalty assessment, threw them all together, and voilá, came out with a $\$ 2$ royalty rate adjustment. ${ }^{148}$ The Federal Circuit considered the testimony admissible, reasoning that it was for the jury to decide the weight given to the evidence in calculating a reasonable royalty. ${ }^{149}$

Similarly, in Parker-Hannifin Corp., the court analyzed the two expert testimonies presented going toward a reasonable royalty award. ${ }^{150}$ After considering all fifteen of the Georgia-Pacific factors in a bench trial, the court,

141. Id. at *7-8.

142. Id. at $* 6$.

143. Dynetix Design Solutions, Inc. v. Synopsys, Inc., No. C 11-05973 PSG, 2013 WL 4538210, at*1 (N.D. Cal. Aug. 22, 2013).

144. Id. at $* 2-3$.

145. Id.

146. Id. at $* 4$.

147. i4i Ltd. P'ship v. Microsoft Corp., 598 F.3d 831, 854 (Fed. Cir. 2010).

148. Id. at 853-54.

149. Id. at 856 .

150. Parker-Hannifin Corp. v. Champion Labs., Inc., No. 1:06-CV-2616, 2008 WL 3166318 , at *4-7 (N.D. Ohio Aug. 4, 2008). 
in coming to its reasonable royalty award of $\$ 203,524$, reasoned that "[f]ive of the factors point toward a higher royalty rate and three point toward a lower rate. Six of the factors are neutral or would have no effect." conclusory remarks are often all that reviewing judges have to determine the sufficiency of a verdict and/or the admissibility of the evidence.

The preceding cases illustrate the inefficiency and inadequacy of the current reasonable royalty assessment under the Daubert standard, and specifically, the unreviewable application of the Georgia-Pacific factors. With the extensive time and substantial amounts of money invested in experts and damages assessments in general, ${ }^{152}$ it is an unfortunate reality that those resources are sometimes spent with nothing to show for it. But as the next section illustrates, there are simple guidelines that courts can put into place that, if followed, can largely eliminate these costly procedures.

\section{OUTLINE OF SOLUTIONS}

In light of the problems with the reasonable royalty framework, many commentators have suggested varying degrees of reform. Some have proposed reform by capping damages with the value of the "next best" alternative investment to the infringer, ${ }^{153}$ while others have suggested doing away with the Georgia-Pacific factors altogether, ${ }^{154}$ and still others have suggested streamlining the calculation by using industry average royalty rates as the award amount. ${ }^{155}$ Although these propositions have strengths, they also have the potential to give insufficient weight to the uniqueness of technology and its value in different applications, ${ }^{156}$ or they may be inconsistent with current jurisprudence. ${ }^{157}$

151. Id. at *4 (emphasis added).

152. See supra note 119 and accompanying text.

153. Epstein \& Malherbe, supra note 75, at 33; see also Seaman, supra note 43, at 1667 (reasoning that a "rational accused infringer would pay only the amount that it would cost to obtain ... and implement the substitute technology ....").

154. See generally Daralyn J. Durie \& Mark A. Lemley, A Structured Approach to Calculating Reasonable Royalties, 14 LEWIS \& CLARK L. REV. 627 (2010) (suggesting that boiling down the Georgia Pacific factors into three basic questions would simplify the question for the jury and simplify the court review process); see also Seaman, supra note 43, at 1726.

155. See Schmitt-Nilson, supra note 101, at 53.

156. See generally Dowagiac Mfg. Co. v. Minnesota Moline Plow Co., 235 U.S. 641, 648 (1915) (holding that the calculation of a reasonable royalty should consider "the nature of the invention, its utility and advantages, and the extent of the use involved").

157. See, e.g., Mars, Inc. v. Coin Acceptors, Inc., 527 F.3d 1359, 1373 (Fed. Cir. 2008) (concluding that it is "wrong as a matter of law to claim that reasonable royalty damages are capped at the cost of implementing the cheapest available, acceptable, noninfringing alternative."); ParkerHannifin Corp. v. Champion Labs., Inc., No. 1:06-CV-2616, 2008 WL 3166318, at *9 (N.D. Ohio Aug. 4, 2008) (reasoning that Mars, Inc. v. Coin Acceptors, Inc. compelled the court "to revisit its earlier determination that the reasonable royalty for the provisional rights period should be capped by the amount defendant would have spent to design around plaintiff's patent."); see also IP Innovation LLC v. Red Hat, Inc., 705 F. Supp. 2d 687, 690-91 (E.D. Tex. 2010) (excluding expert 
Additionally, there is something to be said for retaining the framework currently in place, with slight modification, rather than implementing an entirely new standard to which litigants must acclimate.

In contrast to these propositions, this proposal accounts for both accuracy and efficiency by requiring a real-world licensing analogy as a starting point in assessing a reasonable royalty award. This, in turn, would greatly improve the predictability of the patent litigation process, and thereby economize the increasing costs of patent litigation. Once a damages starting point is established, the Georgia-Pacific factors can then act as adjusters to make up for the deficit resulting from consideration of the licensing analogy, where the greater the value diverges from the initial starting point, the greater scrutiny the court should administer to the assessment (i.e., stricter gatekeeping). In addition, there should be a mandate for damages evidence to include quantitative assessments attached to each adjusting factor such that it compels reasoned support for the adjustment, as required under the Daubert standard. ${ }^{158}$ This mandate would allow the evidence to be maintained, at least in part, if some is later deemed insufficient.

\section{A. Making it Predictable: A Real-World Analogous License Starting Point}

The first part of this proposal requires a comparable license to be admitted ${ }^{159}$ by the judge in a judicial gatekeeping role. Again, once admitted, the judge then increasingly scrutinizes adjustments as they depart further and further from the comparable license starting point to increase predictability. This essentially makes the second factor of Georgia Pacific ${ }^{160}$ a threshold requirement in all reasonable royalty assessments.

Recently, former Chief Judge Randall Rader of the Federal Circuit was asked, "Is there a more methodologically sound way to address the reasonable royalty issue?"161 Judge Rader responded, in part, by stating:

We are trying to decide what this claimed invention, which is a . . component of a larger device or process, what is the value of that component? Well, that's like, is it a countertop or is it a second-car

testimony partially because it improperly relied on industry average royalty rates).

158. See FED. R. EVID. 702 advisory committee's note ("The trial judge in all cases of proffered expert testimony must find that it is properly grounded, well-reasoned, and not speculative before it can be admitted.").

159. See Apple Inc. v. Motorola, Inc., 757 F.3d 1286, 1325 (Fed. Cir. 2014) ("[U]sing sufficiently comparable licenses is a generally reliable method of estimating the value of a patent.").

160. Georgia-Pacific Corp. v. U.S. Plywood-Champion Papers, Inc., 318 F. Supp. 1116, 1120 (S.D.N.Y. 1970) ("The rates paid by the licensee for the use of other patents comparable to the patent in suit.").

161. John Bone et al., View from the Federal Circuit: An Interview with Chief Judge Randall R. Rader, SRR JOURNAL, http://www.srr.com/article/view-federal-circuit-interview-chief-judgerandall-r-rader (last visited Oct. 19, 2014), archived at http://perma.cc/5BWC-J9VF. 
garage? The realtors can [evaluate the enhancements]. Why can't we? ${ }^{162}$

Obviously, countertops and second-car garages do not vary substantially from house to house in terms of their added value, whereas patents do, being unprecedented by definition. ${ }^{163}$ However, along the lines of Chief Judge Rader's comments and in contrast to the permissive use of comparable licenses in cases akin to Uniloc, ${ }^{164}$ there exists a sufficient real-world licensing analogy to act as a starting point for every reasonable royalty damages assessment. Requiring the gatekeeping judge to make this determination as a matter of law before handing the decision to the fact-finder will increase the predictability of reasonable royalty assessments.

By "sufficient," this Note acknowledges that all third-party licenses are unique to some extent, but finding the closest license to the technology and situation at issue and then being transparent as to the differences allows factfinders to weigh the differences and account for them accordingly. ${ }^{165}$ Then, based on the expert-illuminated differences between licenses, Georgia-Pacific adjustments can closer approximate the actual royalty rate to which the parties would have agreed (i.e., account for the application-specific use of the technology).

Case law provides support for the proposition that a comparable license likely exists for every reasonable royalty determination. For example, in Lucent, the court addressed the comparability of eight different licensing agreements. ${ }^{166}$ The court was not impressed with the expert's comparability justification for four of the licenses because the patentee merely explained that they covered "PC-related patents." 167 For the remaining agreements, the court explained, "we are simply unable to ascertain from the evidence presented the subject matter of the agreements." 168 The court went on to explain, "without more information about the [proffered] agreement, one can only speculate about how the [proffered] agreement could be compared to any licensing agreement involving" the patent at issue. ${ }^{169}$ Implicit in the courts reasoning is that more information about the proffered licenses in light of the patent and parties at issue may have made them sufficiently comparable. ${ }^{170}$

Similarly, Finjan, Inc. v. Secure Computing Corp. provides support for the

162. $I d$.

163. The author of this Note is not implying that former Chief Judge Rader meant to say that patents and household improvements are directly analogous.

164. Uniloc USA, Inc. v. Microsoft Corp., 632 F.3d 1292 (Fed. Cir. 2011).

165. See infra notes 171-74 and accompanying text.

166. Lucent Tech., Inc. v. Gateway, Inc., 580 F.3d 1301, 1327 (Fed. Cir. 2009).

167. Id. at 1328 .

168. Id.

169. Id.

170. See also ResQNet.com, Inc. v. Lansa, Inc., 594 F.3d 860, 870 (Fed. Cir. 2010) ("none of [the proffered] licenses even mentioned the patents in suit or showed any other discernible link to the claimed technology," which seems to imply that the licenses may have been comparable had sufficient testimony been given). 
proposition that there exists a sufficiently comparable license to be utilized in every reasonable royalty determination. ${ }^{171}$ In Finjan, the Federal Circuit affirmed a jury's damages award, in part, because Finjan's expert highlighted the differences between the proffered license and the situation at issue. ${ }^{172}$ For instance, Finjan's expert explained: (1) Finjan did not compete with the party to the license, whereas they did compete with the defendants; (2) Finjan received significant intangible value from the endorsement of the party to the license; and (3) the license involved a lump sum instead of a running royalty. ${ }^{173}$ The court stated that the expert's testimony as to the differences between the proffered license and the situation at issue "permitted the jury to properly" weigh the license in coming to its verdict. ${ }^{174}$ Thus, there seems to be a trend that expert transparency is key to the admissibility of what otherwise may be insufficient evidence.

Furthermore, there is a general trend for judges to throw out comparable licenses where transparency has not been present. Courts have been highly skeptical of "licenses" utilized where no real comparison is even possible. For example, sweeping estimations, like the twenty-five percent rule-of-thumb, have no basis in fact, and thus cannot be compared at all. ${ }^{175}$ Similarly, the use of industry average royalty rates has no possibility of comparison because of the vast array of technology it takes into account (e.g., all inventions in the electronics industry) and thus has no place in a comparability assessment. ${ }^{176}$

Likewise, courts have been skeptical where experts seemingly attempt to mislead the factfinder. For example, in Laser Dynamics, Inc. v. Quanta Computer, Inc., the expert tried to rely on a settlement agreement, as a comparable license, where the settlement agreement was "six times larger than the next highest amount paid for a license to the patent-in-suit." ${ }^{\text {"177 }}$ The court admitted that settlement agreements can be relevant, but where, as here, there were "twenty-nine" other licenses for the patent-in-suit, which did "not involve the unique coercive circumstances of the ... settlement agreement," then using the settlement agreement to merely increase the damages assessment was prohibited. ${ }^{178}$ Implicit in the court's reasoning is that whether a license is comparable is a relative inquiry. Had the expert been completely transparent as

171. See Finjan, Inc. v. Secure Computing Corp., 626 F.3d 1197, 1211-12 (Fed. Cir. 2010).

172. Id. at 1211-12.

173. Id. at 1212 .

174. Id.; see also ActiveVideo Networks, Inc. v. Verizon Commc'n, Inc., 694 F.3d 1312, 1333 (Fed. Cir. 2012) (holding that the evidence of comparable licenses was properly admitted even though the agreements did not involve the patents-in-suit or cover the technologies at issue in the case).

175. Uniloc USA, Inc. v. Microsoft Corp., 632 F.3d 1292, 1315 (Fed. Cir. 2011).

176. See IP Innovation LLC v. Red Hat, Inc., 705 F. Supp. 2d 687, 690-91 (E.D. Tex. 2010) (excluding expert testimony partially because it presumptively relied on industry average royalty rates).

177. LaserDynamics, Inc. v. Quanta Computer, Inc., 694 F.3d 51, 78 (Fed. Cir. 2012).

178. Id. 
to the comparability of the licenses at issue, he likely would not have considered submitting the settlement agreement because of the availability of more comparable licenses.

In deciding which license to admit, the issue arises as to what judges should be looking for in the transparency of expert assessments for comparable licenses. The difficulty in determining comparability, a fact-intensive determination, is that the requirements are still vague and, unfortunately, there is no shortage of ways that licenses can differ. For example, patents may differ in "licensing exclusivity, duration, field of use, and potential overlap and competition with the [patentee's] own sales." ${ }^{\text {"179 }}$ Furthermore, patents can differ in the additional investment required to reach feasible commercialization (e.g., research and development). ${ }^{180}$ Thus, differences between licenses can be enormous, making the rigorous evidential requirements of the likes of Daubert all the more difficult.

However, useful resources are available for adequately determining the comparability of licenses. Various intellectual property information services make it their business to determine royalty rates in various circumstances. For example, in researching comparable licenses, one such service recommends breaking down licenses piece by piece in accommodating for the licenses' differences and similarities. ${ }^{181}$ Additionally, the Code of Federal Regulations considers a number of factors in determining the comparability of intangibles. ${ }^{182}$ Relevant non-exclusive factors for determining the comparability of intangibles include: (i) the similarity of products or processes, as used in connection with the intangible, within the same general industry or market; (ii) the intangible's profit potential; (iii) the terms of the transfer; (iv) the stage of development; (v) the duration of the license; and (vi) the product liability risks. ${ }^{183}$ Again, the key is that experts bring to light all such differences so the judge can then admit the most comparable license as a starting point in the reasonable royalty determination.

Additionally, although a potentially arduous task, using past licenses as a mandatory starting point in a reasonable royalty analysis has great possibilities in terms of refinement and increasing predictability because of the breadth of information available. ${ }^{184}$ For example, many countries, including the United States and Canada, require public companies to provide license agreement information (e.g., terms, rates, parties, product descriptions) in publicly available

179. Epstein \& Malherbe, supra note 75, at 8 (explaining that the value of a patent may differ depending on the existence of various factors, e.g., available alternatives, "strength" of protection, etc.).

180. Id.; see also Jarosz et al., supra note 43, at 820-24 (providing expert guidance about the various dimensions of license comparability).

181. David Jarczyk, Replacing the 25 Percent Rule with Fact-based Evidence, KTMINE (Oct. 7, 2013), http://www.ktmine.com/wp-content/uploads/2014/04/Replacing-the-25-Percent-Rule.pdf, archived at $\mathrm{http}: / /$ perma.cc/93LE-ZX5E.

182. 26 C.F.R. $\S 1.482-4$ (2014).

183. Id. $\S 1.482-4(\mathrm{c})(2)(\mathrm{iii})(\mathrm{B})$.

184. See Jarczyk, supra note 181. 
repositories. ${ }^{185}$ And, as posited by one commentator, similar repositories will become more accessible and accurate as their necessity becomes apparent:

To the extent the governing legal standard[] provide[s] incentives for repeat players to develop better databases on comparable licenses, for experts to develop specialties in identifying and quantifying next-best alternatives, and for lawyers to develop methods for teaching juries to understand the relationship between royalty rates and bases . . the market for the necessary information will evolve. ${ }^{186}$

Thus, the accessibility of information useful for identifying a sufficiently comparable license will certainly grow.

It is true that comparable licenses have been used in supporting vastly differing expert opinions of reasonable royalty awards. To draw on a previous example, in i4i Limited Partnership, one party used a comparable license to come to a total damages amount of $\$ 200$ million, whereas the opposing party used comparable licenses to come to a total damages amount of $\$ 1$ million to $\$ 5$ million. ${ }^{187}$ However, if parties knew that the judge was going to admit one or, on rare occasion, more than one comparable license as a reasonable royalty damages starting point with relative certainty of little divergence, then parties would surely be motivated to locate the most comparable license(s) available. This is especially true because an insufficiently comparable license, albeit favorable, would run the risk of being barred by the judge from admission to the jury. Then, the jury can consider the remaining admitted Georgia-Pacific factor analysis in adjusting the comparable license starting point. ${ }^{188}$ However, parameters also need to be set for admitting damages adjustment evidence (i.e., the remaining GeorgiaPacific factors).

\section{B. Making it Reviewable: Numerical Associations with Georgia-Pacific Adjustments and Increasingly Scrutinizing Admittance}

Accuracy is a luxury that courts have resolved to give less influence than likely preferred in reasonable royalty determinations because of the competing policy rationales behind the rules of evidence - efficiency and accuracy. ${ }^{189}$ For example, courts have consistently recognized that "a reasonable royalty analysis "necessarily involves an element of approximation and uncertainty.", 190

185. See id.; see also Michael J. Chapman, Using Settlement Licenses in Reasonable Royalty Determinations, 49 IDEA 313 (2009) (proposing settlement licenses should also be allowed in determining a comparable license which would broaden the pool of licenses available for comparison).

186. Cotter, supra note 43, at 759.

187. i4i Ltd. P'ship v. Microsoft Corp., 598 F.3d 831, 853 (Fed. Cir. 2010); i4i Ltd. P'ship v. Microsoft Corp., No. 2009-1504, 2009 WL 2955399 (Fed. Cir. Aug. 25, 2009).

188. Under this proposal, it is important for judges to emphasize to the jury that the starting point is just that and not the end point (i.e., juries can adjust the starting point).

189. FED. R. EVID. 102.

190. Lucent Techs., Inc. v. Gateway, Inc., 580 F.3d 1301, 1336 (Fed. Cir. 2009); see also 
However, one way of eliminating some of the uncertainty in reasonable royalty calculations is by requiring all evidence associated with the Georgia-Pacific factors to have numerical associations, or ranges, under which the evidence can be evaluated. As Judge Posner recently remarked, reasonable royalty assessments are "not bound to absolute precision. ... . But there has to be a responsible effort at quantification in order to justify a specific award." recently alluded to this desire in Whitserve, LLC v. Computer Packages, Inc. when it stated, "[e]xpert witnesses should concentrate on fully analyzing the applicable factors, not cursorily reciting all fifteen. And, while mathematical precision is not required, some explanation of both why and generally to what extent the particular factor impacts the royalty calculation is needed.",192

In Whitserve, the court vacated the jury's damages award and remanded for a new trial on damages, in part because the patentee's expert's testimony as to reasonable royalty damages was "speculative." 193 There, the patentee's expert "testified that almost all [the Georgia-Pacific] factors justified an increase in the applicable rate" and "a few were neutral in terms of their impact." 194 One example of the expert's speculative analysis was of factor nine: "The ninth factor refers to the advantages of a patented product over the old method. . . . Basically there's a whole host of [the defendant's] internal documents that discuss the disadvantages of the old paper-based process prior to 2002, and that would support a higher royalty rate." 195

As previously explained, judges often defer to jury determinations simply because under the current framework it is difficult to tell whether there is sufficient evidence to support their final determination of a reasonable royalty award. ${ }^{196}$ Generally, all that is required in a verdict is that juries state the total award. ${ }^{197}$ However, if all evidence relevant to the Georgia-Pacific factor adjustment is required to have an associated numerical value, or value range, then courts could more adequately assess the sufficiency and adequacy of the evidence submitted to the jury-knowing full well which factors were admitted for consideration and their relative numerical weights. This would not only force experts to provide more adequate justifications for their often sweeping and qualitative assertions regarding the weight given to Georgia-Pacific adjustments, but it would also allow for greater efficiency and predictability in post-trial

Apple Inc. v. Motorola, Inc., 757 F.3d 1286, 1315 (Fed. Cir. 2014) (“[E]stimating a 'reasonable royalty' is not an exact science").

191. Bone et al., supra note 51.

192. Whitserve, LLC v. Computer Packages, Inc., 694 F.3d 10, 32 (Fed. Cir. 2012) (emphasis added); but see Apple, Inc. v. Samsung Elec. Co., Ltd., No.: 11-CV-01846-LHK, 2014 WL 549324, at *5-6 (N.D. Cal. Feb. 7, 2014) (concluding that the expert's Georgia-Pacific factor analysis was sufficient even though she did not attach any relative numerical weights to the factors).

193. Whitserve, $L L C, 694$ F.3d at 29.

194. Id. at 31.

195. Id. at $31 \mathrm{n} .15$.

196. Durie \& Lemley, supra note 154, at 628.

197. Seaman, supra note 43, at 1709 (citation omitted). 
procedures regarding the reasonable royalty award. Additionally, the attachment of numerical values to each piece of admitted evidence will likely give jurors more confidence in their final calculations. In the absence of such a requirement, juries potentially ignore the Georgia-Pacific evidence altogether and come out with a best guess. ${ }^{198}$

Although a potentially minor evidentiary requirement, the change could bring about substantial improvements to reasonable royalty jurisprudence. As previously mentioned, "the Federal Circuit's reversal rate has approached 50\% with the reasonable royalty damages being reversed in eight cases and affirmed in [ten]." 199 This is likely because there is no way a judge can say that a damages award is supported by "substantial evidence"200 without knowing what was considered to reach it. Were experts required to quantifiably account for each adjustment to the pre-determined comparable license starting point, judges could clearly see how a jury reached the award amount it did and review the particular evidence associated with those adjustments. Then, the judge could determine whether the evidence was sufficiently "substantial." In the absence of such a requirement, when courts decide to throw out reasonable royalty expert testimony, the result is inefficient because one misstep in the expert's testimony can sacrifice the entirety of the evidence, which leads to an even greater possibility of disproportionality in a jury's final determination.

Additionally, the requirement to have Georgia-Pacific factors with attached numerical assessments would complement the requirement to use a comparable license as a starting point, because each expert's evaluation and subsequent admission would be independently verifiable. That is, once the judge determines the comparable license starting point, the admissible Georgia-Pacific factors from either party are unaffected because the numerical associations with each factor can be independently considered and applied for adjustment to the starting point where relevant.

For example, say the accused infringer proposes a comparable license starting point of \$5/unit with an upwards adjustment of \$2/unit after considering all fifteen Georgia-Pacific factors, for a final royalty of \$7/unit. However, operating under the proposed framework of using a comparable license as a starting point, the judge decides that the patentee's comparable license of $\$ 15 /$ unit is the appropriate starting point and three of the fifteen Georgia-Pacific factors were improperly applied or supported by the accused infringer. What other choice does the judge have than to throw out all the evidence presented by the accused infringer because there is no indication as to the apportionment of the remaining factors considered? In other words, if three of the factors were improperly considered, there is no way for the judge to know how much those three factors

198. Martha K. Gooding \& William C. Rooklidge, The Real Problem with Patent Infringement Damages, 91 J. PAT. \& TRAdEMARK OfF. SoC’Y 484, 489 (2009) (“Jurors . . . appear to be confounded by the Georgia-Pacific factors, what they mean, and how to apply them. As a consequence ... jurors tend to ignore them.").

199. SKENYON, supra note $35, \S 3: 2$.

200. Lucent Techs., Inc. v. Gateway, Inc., 580 F.3d 1301, 1325 (Fed. Cir. 2009). 
contributed to the overall \$2/unit adjustment. Judges could, and often do, allow the accused infringer to testify again based on the new comparable license starting point, ${ }^{201}$ but that is costly and inefficient. Thus, requiring individual numerical associations will have the added efficiency benefit of preserving the sufficient expert testimony of both parties for jury consideration.

\section{Impact of Proposal on NPEs}

This proposed framework has the added benefit of chipping away at the litigation strength of NPEs, because it allows potential litigants to more accurately predict what a case brought by a NPE is actually worth. Not only does it chip away at the power of NPEs in patent litigation, but it does so with relatively little change and without the involvement of Congress.

It is useful here to return to the catch-22 in which some patent litigants find themselves with NPEs: "The patent troll offers a license for under $\$ 100,000$. The end user makes a business decision - millions of dollars to defend a suit that might be lost, or $\$ 100,000$ or less for certainty? The end user takes a license."202 However, under the proposed framework that makes reasonable royalty damages more predictable, an accused infringer is in a better position to determine whether the margin between settlement costs and potential liability costs is sufficient to warrant forgoing the offered settlement and charge full steam ahead into litigation with the NPE. Settlement licenses will only be extracted from those parties who recognize that the potential costs of litigation far exceed the costs of settlement. And those who move forward with litigation and then appeal have the added predictability of the sufficiency of their evidence in downwardly adjusting the jury's award. The accused infringer can rest assured that the insufficiency of some of their evidence will not have an adverse effect on the entirety of their expert testimony, thus preserving the cost of more litigation expenses.

\section{CONCLUSION}

To repeat, this Note's proposal is two-fold. First, courts should require the use of comparable licenses as a starting point in every reasonable royalty analysis, and the court, in its gatekeeping role, should admit only the most comparable license for the jury's use as a damages award starting point. Second, courts should require experts to attach numerical associations to each Georgia-Pacific factor assessment such that the any reviewing judge can effectively and accurately evaluate the evidence. As the damages assessment diverges from the comparable license starting point, courts should increase the scrutiny by which they admit these numerical factor associations.

Returning to the introductory hypothetical, this proposal remedies the illustrated issues by allowing Party $\mathrm{Y}$ to make a sound fiscal decision as to

201. See, e.g., Dynetix Design Solutions, Inc. v. Synopsys, Inc., No. C 11-05973 PSG, 2013 WL 4538210, at *5 (N.D. Cal. Aug. 22, 2013) (permitting resubmission of damages testimony because the presented evidence was insufficient).

202. Cahr \& Kalina, supra note 123 , at 16. 
whether to defend against X's patent infringement allegations or settle because $\mathrm{Y}$ can more accurately predict any damages that could result. Furthermore, if Y does decide to defend, s/he can be sure that the resources $s /$ he invests in defending will not be wasted by inefficient procedures.

Thus, the added certainty provided by this framework (1) more effectively implicates the underlying rationale of the United States patent system-to incentivize innovation; (2) conserves resources judicially, legislatively, and for the respective parties; and (3) adversely affects NPEs by taking away some of their bargaining strength in litigation. 